\title{
CONTENT OF HEALTH RELATED SHAPING TRAINING METHODIC FOR GIRLS IN THE PROCESS OF PHYSICAL EDUCATION
}

Skidan A.A. ${ }^{1}$, Sevdalev S.V. ${ }^{1}$, Vrublewskiy E.P. ${ }^{1,2}$

${ }^{1}$ Francisk Skorina Gomel State University, Republic of Belarus

${ }^{2}$ University of Zielona Góra, Poland

\begin{abstract}
Purpose: theoretical substantiation, working out and testing of health related trainings with girl students, practicing shaping in their physical education. Material: in the research 22 girl students of pedagogic specialties participated. Experiment stipulated usage of shaping methodic, based on computer program, during academic year. Results: experimental methodic of shaping permitted to bring physical condition indicators of experimental group's girls to patterns of computer program. Analysis of the received data of body circumferential sizes did not show statistically confident distinctions from ideal patterns $(\mathrm{p}>0.05)$ that witness about their similarity. Results of abdomen top and bottom, torso sides and bottom of back fat folds' measurements did not confidently differ from patterns $(p>0.05)$. The above mentioned indicators were within normal values. With it difference for $5 \%$ of significance level was registered in the tested functional indicators of girl students, comparing with initial data. After experiment systolic and diastolic BP practically approached to normal value. Heart beats rate confidently approached to normative indicators. Conclusions: application of health related shaping methodic positively reflected on physical condition and functional state of girl students. We also proved that it was possible to use computer program for composing individualized training programs.
\end{abstract} Key words: girl students, shaping, computer program, ideal patterns, physical condition, functional state.

\section{Introduction}

Recent years, students' health has been being of great concern, in spite of established opinion that youth is the healthiest category of population [2, 6, 9, and 14]. At present this group of population is socially vulnerable and do not have or do not use opportunity of its full development.

Only for recent decade the quantity of weakened students has been increased more than 2 times. Analysis of youth's health, physical condition and physical fitness shows that morbidity among students is increasing $[3,7]$, physical condition and physical fitness are weakening $[3,16]$. The quantity of students released from practical physical culture lessons by health reasons increases as well as quantity of students - members of special health groups [2, 16]. In Belarus $70 \%$ of students do not practice physical culture. Students' physical inactivity reached $80 \%$. Incorrect and irrational eating resulted in the fact that more than $30 \%$ of students have deficit of body mass. The same quantity of students has excessive weight $[6,15]$. This problem is especially sharp for girls, having excessive fat. Such girls have increased body mass. All these influence on motor functioning and functioning of all organism's organs and systems, on psychic health [4, 18].

Researches of recent years show $[11,14,16]$, that standard form of organization of physical culture lessons for HEE students is ineffective. It does not facilitate formation of sufficient motivation for physical functioning and does not ensure compensation of students' motor functioning deficit.

Involvement of students in physical trainings and formation of their conscious attitude to them is still an acute problem [4, 7]. Girl students to large extent are not satisfied with traditional forms of HEE physical education. They have increased interest to new non traditional kinds of health related physical culture activity.

In opinion of many authors [1, 4, 11, 13, 20-23], girls prefer physical functioning, containing exercises' complexes, which could influence on morphological functional indicators of woman's organism. In 18-21 years' age girls pay special attention to beauty, flexibility, mobility of their bodies. That is why girls wish to practice exercises, which would facilitate harmonious body constitution. It attracts attention of opposite sex. Girl students prefer methods, connected with music, plasticity, artistry. For them first of all positive emotions, possibility to aesthetically influence on organism by physical exercises are important.

In this connection education system in general and HEEs in particular face the task of maintenance of students' physical, psychic and moral health. That is why HEE shall be an initiator and organizer of purposeful and effective work on rehabilitation, protection and strengthening of students' health. At present this work is acquiring systemic character: new health related and diagnostic technologies are implemented; material-technical base of HEEs rises [10, 15].

(c) Skidan A.A., Sevdalev S.V., Vrublewskiy E.P., 2015

http://dx.doi.org/10.15561/20755279.2015.0608 
In many developed countries different directions of health related physical culture are intensively developing. Great number of new body correction programs, strengthening and protection of woman's health appear $[11,17]$.

Recent years a number of new, modern health related physical culture systems and technologies, which are practiced mainly by girls, has appeared [11]. Among many kinds of physical functioning shaping has been taking first place during more than 20 years. With it shaping quickly develops and perfects. In opinion of many specialists modern shaping permits to effectively solve tasks of physical, mental and aesthetic perfection [5, 13, and 18].

The content of shaping trainings is determined by personalities strive for beauty and harmony. The basis of the system is idea about standard of physical perfection, which is called "model" in shaping. Such "model" has main signs of woman's beauty and attractiveness. "Shaping" system is a purposeful training of separate muscular groups, which permits for every trainee to correct defects of posture in all parts as well as to reduce weight, to improve carriage, to acquire body beauty, for which all modern girls strive. Harmonious body is one of main signs of human health, as far as defects of body hinder functioning of organism's organs and functions [5, 8, and 13].

\section{Purpose of the research, material and methods}

The purpose of the research is theoretical substantiation, working out and testing of health related trainings with girl students, practicing shaping in their physical education.

The methods and materials of the research: analysis of scientific-methodic literature was carried out in order to know existing views on the studied problems, on perfection of students' physical education.

Pedagogic observations were conducted during all period of work. The object of observation was fulfillment of the worked out methodic approaches to physical education means' application by the tested. Results were assessed by express tests and by external signs of fatigue.

Girls' testing was conducted with the help of special computer program "Shaping" [11]. The program included measurement of anthropometric indicators: a) body mass and body length; b) circumferential sizes of neck, chest, breast, waist, buttocks, hips, shins, knees, wrists; c) fat folds on forearm, front and back of shoulder, top and bottom of back, top and bottom of abdomen, front and back, inside and outside of hips; change of cardio-vascular system's indicators: blood pressure and heart beats rate (HBR). All mentioned above information was processed by computer program. By results of this processing ideal values for such contingent were received.

Besides, we used commonly accepted methods of mathematical statistic. Confidence of distinctions was determined with Student's t-criterion.

Pedagogic experiment was conducted on base of Gomel health related physical culture center during academic year. Experiment was organized ob the base of generally accepted principles. In the research 22 girl students of pedagogic specialties participated. They were trained by shaping program twice a week (60 minutes - each training session). It should be noted that experimental group of girl students was formed by selection of girls with excessive fat. The purpose of trainings was to correct their figures in general and change configuration of separate parts of their bodies. In experimental group we realized methodic of shaping training, facilitating purposeful body corrections, considering ideal values for this contingent. For this purpose we used results of special computer program "Shaping".

He offered by computer program complexes of exercises and methodic of their application are directed on correction of body parts, which deviate from standard. In process of training complexes were corrected in order to individualize approaches to every girl students. Some complexes of exercises were worked out for increasing of muscular mass (increasing of body parts' volume). Other - were directed on reducing of volumes at the account of fat decreasing. Complexes of exercises were combined by prevailing influence on different muscular groups.

Practical significance of the work was assessment of deviations from ideal values. Detection of deviations served as bench mark for targeted impact on separate body parts by shaping means. To larger extent training influence was rendered on those bode parts, which had deviations from standard. Orienting on ideal values we determined direction of correction of every part of body and selected special individual programs of appropriate training.

The structure of practical work in experimental group included execution of exercises, divided into 11 blocks (series) - fore successive work of separate muscular groups (see table 1). 
Table 1. Structure of shaping trainings in experimental group

\begin{tabular}{|c|c|c|c|}
\hline \multicolumn{4}{|c|}{ STRUCTURE OF TRAININGS } \\
\hline & Block for working with muscular groups & Duration (minutes) & Part of training \\
\hline 1 & Warming up & 10 & I Introductory \\
\hline 2 & Hip (front) & 4 & \multirow{8}{*}{ II Main } \\
\hline 3 & Hip (back) & 4 & \\
\hline 4 & Hip (inside) & 4 & \\
\hline 5 & Hip (outside) & 4 & \\
\hline 6 & Buttocks & 4 & \\
\hline 7 & Abdomen (top) & 4 & \\
\hline 8 & Abdomen (bottom) & 4 & \\
\hline 9 & Waist & 4 & \\
\hline \multirow[t]{4}{*}{10} & Individual block & & \multirow{4}{*}{ III Additional } \\
\hline & - first zone & 4 & \\
\hline & - second zone & 4 & \\
\hline & - third zone & 4 & \\
\hline 11 & Recreation & 6 & IV Finalizing \\
\hline
\end{tabular}

\section{Results of the research}

The received numerical values permitted to detect existing deviations from norm of anthropometric indicators at the beginning of pedagogic experiment.

Body mass of girls actually exceeded normal values at the beginning of experiment (by $6.71 \pm 0.23 \mathrm{~kg}$ ). The highest deviations were detected in fat folds. For example abdomen (top and bottom) had deviations $7.37 \pm 0.17 \mathrm{~cm}$; side of torso $-6.18 \pm 0.22 \mathrm{~cm}$; bottom of back $-11.17 \pm 0.23 \mathrm{~cm}$; hips (front, back, inside, outside) respectively $-12.2 \pm 0.23$, $21.86 \pm 0.26,11.91 \pm 0.20$ and $27.36 \pm 0.22 \mathrm{~cm}$.

By all tested indicators we registered confident difference $(\mathrm{p}<0.05)$ between physical condition indicators and standard indicators (SI).

By the end of pedagogic experiment, between experimental groups' physical condition data and ideal indicators we found confidential difference in measurements of the following fat folds: hip (front) $(19.47 \pm 0.31 \mathrm{~cm})$ deviation from SI- $4.47 \pm 0.27 \mathrm{~cm}$; hip (back) $-26.45 \pm 0.13 \mathrm{~cm}$, deviation from SI $-10.45 \pm 0.21 \mathrm{~cm}$; hip inside $-12.71 \pm 0.17 \mathrm{~cm}$, deviation from SI - 3.21 $\pm 0.18 \mathrm{~cm}$; hip outside $-31.31 \pm 0.21 \mathrm{~cm}$, deviation from SI $-11.31 \pm 0.27 \mathrm{~cm}$. However, in comparison with the beginning of experiment deviations from standard indicators reduced significantly.

Analysis of circumferential sizes of body showed: waist $-63.93 \pm 0.36 \mathrm{~cm}$, deviation from SI $-1.12 \pm 0.26 \mathrm{~cm}$; buttocks - 91.27 $\pm 0.34 \mathrm{~cm}$, deviation from SI $-1.33 \pm 0.32 \mathrm{~cm}$; hips $-52.29 \pm 0.23 \mathrm{~cm}$, deviation from SI $-0.81 \pm 0.22 \mathrm{~cm}$ ) and did not revealed confident distinctions from standard indicators ( $p>005)$. It witnesses about their closeness to model indicators.

Results of abdomen fat folds (top $-8.84 \pm 0.15 \mathrm{~cm}$, deviation from SI $-2.32 \pm 0.14 \mathrm{~cm}$, bottom $-12.84 \pm 0.21 \mathrm{~cm}$, deviation from SI- $2.84 \pm 0.19 \mathrm{~cm}$; fat folds on side of torso $-7.75 \pm 0.24 \mathrm{~cm}$, deviation from SI $-1.83 \pm 0.24 \mathrm{~cm}$; fat folds on bottom of back $-19.98 \pm 0.23 \mathrm{~cm}$, deviation from SI $-0.99 \pm 0.31 \mathrm{~cm}$ also did not confidently differ from standard indicators $(\mathrm{p}>0.05)$. The delivered above indicators are within norm.

Thus, the offered by us health related shaping methodic permitted to practically approach physical condition indicators of experimental group's girls to standard indicators.

Results of research of experimental group girls' cardio-vascular system deviated from norm at the beginning of experiment. They had increased systolic BP (128.74 \pm 0.47 mm.merc.col.) and diastolic BP (87.54 \pm 0.34 mm.merc.col.). 
Also, at the beginning of pedagogic experiment we registered increase of heart beats rate ( $73.35 \pm 0.16$ with norm 60-70 b.p.m.).

After finishing of pedagogic experiment we registered confident change in the tested indicators of girl students' functional state, in comparison with initial data $(\mathrm{p}<0.05)$. Systolic and diastolic BP values were practically normal at the end of experiment (123.65 \pm 0.71 and $84.57 \pm 0.52 \mathrm{~mm}$.merc.col.) Heart beats rate in rest also statistically confidently (for $5 \%$ level of significance) closed to normative indicators at the end of experiment ( $71.23 \pm 0.43$ with norm $60-70$ b.p.m.).

Thus, the worked out methodic of health related shaping trainings turned out to be effective mean of formation of motor culture, physical condition, physical and functional fitness improvement for girls. Results of the research point at purposefulness of implementation of the offered health related shaping trainings methodic for girls in HEE's physical education process.

\section{Discussion}

By results of analysis of scientific-methodic literature and preliminary testing we found that girl students had low level of motor culture, of physical and theoretical fitness (that contradict to requirements of program-normative documents and scientific-methodic recommendations, regulating physical education process of girls students of not physical culture HEEs) $[2,3,5,8,16]$. All these are conditioned by drawbacks of HEE physical education system (orientation only on control normative indicators and body component, ignoring of motivation component of individual motor-developing impacts' application) [3, 4, 6, 7, 9, and 15]. Thus, physical education of not physical culture HEEs' girl students requires correction, considering the mentioned factors.

It should be stressed that physical education process has three vectors of impact: creation of wide circle of knowledge in field of physical culture, training of motor actions (formation of motor culture) and control of physical condition development $[9,10,16$, and 19]. All they are interconnected. Therefore wide usage of physical culture means (including non traditional) facilitates fuller physical and theoretical fitness of girl students. At the same time it is impossible to completely solve physical education tasks without positive motivation background.

As a result of "shaping" computer program every girl realized her own health related effect and could achieve more harmonious and proportional body constitution. The received results show that it is possible for girl students to influence positively on organism in process of physical education. With it perfection of external, visual status is of priority in this age. It is confirmed also by other scientists $[1,6,8,11,13$, and 17]. It is significant that experimental group's girl students started to actively include in independent physical exercises' practicing.

\section{Conclusions}

The conducted pedagogic experiment, health related training methodic permitted to approach every girl to indicators of shaping model. Comparing with the beginning of experiment deviations from ideal standards significantly reduced. Analysis of the received data of circumferential sizes showed that they practically correspond to ideal indicators after experiment. Sizes of fat folds are within norm.

Thus, the worked out shaping methodic permitted to substantially reduce fat component of girl students' body mass, improve functional state, rise psycho-emotional state and motivation for regular physical exercises' practicing, to form steady demand in them. All these confirmed high effectiveness of this methodic, which can be adapted to application in physical education process in conditions of other HEEs and in additional health related training of girl students.

\section{Conflict of interests}

The authors declare that there is no conflict of interests. 


\section{References:}

1. Afonskaia AO. Effektivnost' metodiki formirovaniia osnovnykh priemov ozdorovitel'noj aerobiki u studentov v processe fizicheskogo vospitaniia. Cand. Diss. [Effectiveness of methodic of health related aerobic main techniques formation in students in process of physical education. Cand. Diss.]. Tula; 2004. (in Russian)

2. Belkina NV. Zdorov'e formiruiushchaia tekhnologiia fizicheskogo vospitaniia studentok vuza [Health-forming technology of HEE girl students' physical education]. Teoriia i praktika fizicheskoj kul'tury 2006;2:7-11. (in Russian)

3. Bogatyrev VS. Fizicheskaia kul'tura v vuze [Physical culture in HEE], Kirov: VSPU; 2001. (in Russian)

4. Volodkovich SL. Struktura i soderzhanie ozdorovitel'no-razvivaiushchikh zaniatij po fizicheskoj kul'ture studentok podgotovitel'noj medicinskoj gruppy pedagogicheskikh special'nostej. Cand. Diss. [Structure and content of health related- developing physical culture trainings of special health groups' girl students of pedagogic specialties. Cand. Diss.]. Moscow; 2011. (in Russian)

5. Bochenkova EV, Gubskaia NM. Vliianie fizicheskogo vospitaniia na lichnost' zanimaiushchegosia [Influence of physical education on trainee's personality]. XXVII nauchnaia konferenciia studentov $i$ molodykh uchenykh vuzov Iuga Rossii [27th scientific conference of students and young scientists of the South of Russia], Krasnodar; 2000. P. 15-16. (in Russian)

6. Vrublevskij EP, Skidan AA. Metodika korrekcii teloslozheniia studentok, zanimaiushchikhsia shejpingom v processe fizicheskogo vospitaniia [Methodic of correction of girl students' practicing shaping in process of physical education, body constitution]. II mezhdunarodnaia nauchno-prakticheskaia konferenciia "Cherez fizicheskuiu kul'turu i sport $k$ zdorovomu obrazu zhizni”, 25 maia 2014 g., Ufa [2nd International scientific practical conference "Through physical culture and sports to healthy life style",May 25th, 2014, Ufa], 2014. P. 321-324. (in Russian)

7. Doroshenko SA. Sportivno-vidovoj podkhod v fizicheskom vospitanii studentov v vuze. Cand. Diss. [Sport-species approach in HEE students' physical education. Cand. Diss.], Malakhovka; 2011. (in Russian)

8. Kozlov VI. Progressirovanie deficita dvigatel'noj aktivnosti u studentok $i$ vybor sredstv ego kompensacii. Cand. Diss. [Progressing of motor functioning deficit of girl students and choice of means for its compensation. Cand. Diss.], Malakhovka: MGAFK; 1995. (in Russian)

9. Kovalenko TG. Bioinformacionnye tekhnologii pri problemno-modul'nom obuchenii v sisteme fizicheskogo vospitaniia i reabilitacii studentov s oslablennym zdorov'em. Doct. Diss. [Bio-informational technologies with problem-module education in system of physical education and rehabilitation of students with weak health. Doct. Diss.], Volgograd; 2000. (in Russian)

10. Konikov IA. K voprosu o sushchnosti esteticheskogo [On issue of essence of aesthetic]. Esteticheskoe soznanie lichnosti [Aesthetic consciousness of personality], Moscow: IFRAN; 1994. (in Russian)

11. Los' EE, Glaz'ko TA. Shejping: organizaciia samostoiatel'nykh zaniatij [Shaping: organization of independent trainings], Minsk; 2013. (in Russian)

12. Postol OL. Metodika ozdorovleniia studentok vuzov na zaniatiiakh po fizicheskomu vospitaniiu s primeneniem tradicionnykh $i$ netradicionnykh sredstv. Cand. Diss. [Methodic of HEE girl students' health improvement at physical education lessons with application of traditional and non traditional means. Cand. Diss.], Khabarovsk; 2004. (in Russian)

13. Prokhorcev IV, Maslakova E. Shejping - novyj vid ozdorovitel'noj massovoj fizicheskoj kul'tury [Shaping as new kind of health related mass physical culture], Sport i zdorov'e 1992;1:64-68. (in Russian)

14. Sysoev VV. Formirovanie u studentov neprofil'nykh pedagogicheskikh special'nostej potrebnosti v fizicheskom samosovershenstvovanii. Cand. Diss. [Formation of non profile pedagogic specialties' students' demand in physical self-perfection. Cand. Diss.], Bryansk; 2003. (in Russian)

15. Timoshenko VV. Fizicheskoe vospitanie studentov $i$ uchashchikhsia, imeiushchikh otklonenie v sostoianii zdorov'ia [Physical education of students, having deviations from normal health], Minsk; 1995. (in Russian)

16. Treshcheva OL. Formirovanie kul'tury zdorov'ia v usloviiakh sovremennogo obrazovaniia [Formation of health culture in conditions of modern education], Omsk; 2002. (in Russian)

17. Cirkin VI, Bogatyrev VS. Fizicheskoe zdorov'e cheloveka [Physical health of man], Kirov: VSU; 1998. (in Russian) 
18. Shchankina VV. Novye fizkul'turno-sportivnye vidy [New kinds of physical culture and sports],: RSU; 2006. (in Russian)

19. Iudina NM. Metodika opredeleniia i ocenki fizicheskogo potenciala studentov vuza. Cand. Diss. [Methodic of determination and assessment of physical potential of HEE students. Cand. Diss.], Volgograd; 2006. (in Russian)

20. Fomenko E.V., Practical recommendations for the implementation of health technologies to enhance physical fitness of students in extracurricular classes during non-traditional gymnastics. Pedagogics, psychology, medicalbiological problems of physical training and sports, 2014, vol.7, pp. 31-36. http://dx.doi.org/10.6084/m9.figshare.1015385

21. Kurmaeva EV. Fitness - programs as mean of forming of personality physical culture of students. Physical Education of Students 2013;1:37-39. http://dx.doi.org/10.6084/m9.figshare.156355

22. Malenyuk TV, Kosivska AV. Training at sport circle as priority form of organization of students' physical education (on example of shaping). Pedagogics, psychology, medical-biological problems of physical training and sports 2015;4:38-42. http://dx.doi.org/10.15561/18189172.2015.0407

23. Martinova NP. Results of experimental testing of hee girl students' motor skills at aerobic trainings. Physical Education of Students 2015;5:46-53. http://dx.doi.org/10.15561/20755279.2015.0507 


\section{Information about the authors:}

Skidan A.A.; http://orcid.org/0000-0002-7270-888X; lady.skidan@mail.ru; Francisk Skorina Gomel State University; Sovetskaya str., 104, Gomel, 246019, Republic of Belarus.

Sevdalev S.V.; http://orcid.org/0000-0003-0780-9075; sevdalev@mail.ru; Francisk Skorina Gomel State University; Sovetskaya str., 104, Gomel, 246019, Republic of Belarus.

Vrublewskiy E.P.; http://orcid.org/0000-0001-5053-7090; vruevg@yandex.ru; Francisk Skorina Gomel State University; Sovetskaya str., 104, Gomel, 246019, Republic of Belarus.

Cite this article as: Skidan A.A., Sevdalev S.V., Vrublewskiy E.P. Content of health related shaping training methodic for girls in the process of physical education. Physical education of students, 2015;6:56-62.

http://dx.doi.org/10.15561/20755279.2015.0608

The electronic version of this article is the complete one and can be found online at: http://www.sportpedu.org.ua/html/arhive-e.html

This is an Open Access article distributed under the terms of the Creative Commons Attribution License, which permits unrestricted use, distribution, and reproduction in any medium, provided the original work is properly cited (http://creativecommons.org/licenses/by/4.0/deed.en).

Received: 21.08.2015

Accepted: 05.09.2015; Published: 10.09.2015 